\title{
Gaya Kepemimpinan Kepala Ruang Dengan Kepuasan Kerja Perawat
}

\author{
Muhammad Rijali Rahman ${ }^{1 *}$, Endang Pertiwiwati ${ }^{2}$, Ichsan Rizany ${ }^{3}$ \\ 1,2,3Program Studi Ilmu Keperawatan, Fakultas Kedokteran, Universitas Lambung Mangkurat, \\ Banjarbaru, Indonesia \\ *rijalirahman96@gmail.com
}

\begin{abstract}
Nurse job satisfaction is one of the factors affecting work productivity. Job satisfaction is influenced by the leadership style applied by the chief nurse in leading his subordinates. The purpose of this study was determined the relationship between the leadership style of the chief nurse and the nurse's job satisfaction in the inpatient room at Idaman City Hospital in Banjarbaru. This research approach used cross sectional. The population was all nurses in the inpatient room with a total of 119 nurses. Sampling used quota sampling as many as 102 respondents. There were 3 research instruments used, consisted of questionnaire respondent characteristics, nurse job satisfaction and leadership style of the chief nurse. The method used by events that carry out actions on respondents, has been observed. The correlational and survey approaches used in this study were to present a questionnaire. The leadership style of nurse manager has an average of 57.90 (50-72). Nurse job satisfaction has rather average of 62,82 (3896). There was a relationship between the leadership style of the chief nurse and the nurse's job satisfaction in the inpatient room at Idaman City Hospital in Banjarbaru ( $p$-value =0,000<0.05). The leadership style of the head of the room in accordance with the situation and conditions and good application can produce nurses who are satisfied with their work and can also improve performance in carrying out their duties.
\end{abstract}

Keyword: leadership style, nurse manager, nurse job satisfaction

\begin{abstract}
Abstrak
Kepuasan kerja perawat yaitu salah satu faktor mempengaruhi produktivitas kerja. Kepuasan dalam bekerja dipengaruhi oleh gaya yang diterapkan kepala ruang dalam memimpin bawahannya. Tujuan penelitian ini untuk mengetahui hubungan gaya kepemimpinan kepala ruang dengan kepuasan kerja perawat di ruang rawat inap RSD Idaman Kota Banjarbaru. Pendekatan penelitian ini menggunakan cross sectional dengan desain non eksperimen. Populasi yaitu seluruh perawat pelaksana pada ruang rawat inap dengan jumlah 119 perawat. Pengambilan sampel menggunakan sampling kuota yaitu sebanyak 102 responden. Instrumen penelitian yang digunakan ada 3 yaitu kuesioner karakteristik responden, kepuasan kerja perawat dan gaya kepemimpinan kepala ruang. Penelitian ini bersifat korelasional dengan pendekatan cross sectional. Gaya kepemimpinan kepala ruang memiliki rata-rata 57,90 (50-72). Kepuasan kerja perawat memiliki rata-rata 62,82 (38-96). Ada hubungan gaya kepemimpinan kepala ruang dengan kepuasan kerja perawat di ruang rawat inap RSD Idaman Kota Banjarbaru ( $\mathrm{p}$-value = $0,000<0,05)$. Gaya kepemimpinan kepala ruang yang sesuai dengan situasi dan kondisi serta penerapan yang baik dapat menghasilkan perawat yang puas terhadap pekerjaannya dan juga dapat meningkatkan kinerja dalam menjalankan tugas.
\end{abstract}

Kata kunci: gaya kepemimpinan, kepala ruang, kepuasan kerja perawat

Jurnal Keperawatan Raflesia, Volume 2 Nomor 2, November 2020

ISSN: (p) 2656-6222, (e) 2657-1595 DOI 10.33088/jkr.v2i2.502

Available online: https://jurnal.poltekkes-kemenkes-bengkulu.ac.id/index.php/jkr 


\section{PENDAHULUAN}

Kepuasan kerja yaitu terpenuhinya emosional berupa puas dan gembira akan suatu pekerjaan yang dicintainya. Kepuasan kerja bisa dirasakan pada pekerjaan, diluar pekerjaan, dan campuran diantara keduanya (Maryanto, Tri \& Singgih 2013). Kepuasan kerja perawat yaitu faktor yang mempengaruhi kinerja. Perawat harus selalu menjaga kepuasan kerja disisi yang positif karena ketika perawat merasa tidak puas melakukan pekerjaannya, timbullah penurunan motivasi kehadiran ditempat kerja serta bisa menyebabkan beban kerja perawat yang lain meningkat dan pelayanan yang dihasilkan kurang optimal (Karimah 2013).

Kepuasan kerja perawat salah satunya dipengaruhi oleh gaya kepemimpinan (Sunyoto 2012). Pemimpin yang memberikan kesempatan kepada bawahannya untuk mengemukakan pendapatnya dapat membuat kepuasan tersendiri. Sedangkan pemimpin yang tidak memberikan kesempatan pada bawahannya kebalikan dari partisipatif, dimana rendahnya kepuasan yang dirasakan bawahan (Sunyoto 2012). Berdasarkan penelitian di Amerika Serikat, Kanda, Inggris, Skotlandia dan Jerman dengan 43.000 perawat yang berpartisipasi dari 700 Rumah Sakit menyatakan 17\% sampai 14\% perawat merasa tidak puas. Angka persentase berbeda-beda pada perihal hadir bekerja yang ditunjukan perawat dengan angka 17\%-39\% (Susanti \& Mulyaningsih 2015). Hasil survei kepuasan kerja yang disalah satu rumah sakit pendidikan yaitu Rumah Sakit Universitas Hasanuddin, memperoleh hasil sebanyak $62,1 \%$ puas, dengan standar kepuasan kerja yang diterapkan di rumah sakit tersebut adalah
80\% (Hidaya, Indahwaty \& Alimin 2015). Hasil residensi di RS Stella Maris Makassar menemukan bahwa ketidakpuasan perawat berada pada tingkat sedang. Hal ini dibuktikan bahwa sebanyak $57 \%$ perawat di ruangan menyatakan ketidakpuasan terutama kapada kompensasi yang diberikan oleh rumah sakit (Mangi 2015). Hasil penelitian dengan judul. Hal tersebut dikarenakan keadaan lingkungan kerja, bisa dari kurangnya dukungan yang diterima individu dari rekan setim atau sejawat, atasan yang kurang memberi penghargaan dalam capaian kerja bawahan, dengan kata lain tidak mendukung dan pengawasan yang kurang dalam penilaian kerja (Maryanto \& Singgih 2013).

Gaya kepemimpinan dapat mempengaruhi bawahan, dimana seorang atasan akan memberi suatu pengaruh pada bawahannya baik itu cara berpikir, segi perasaan, tanggapan ataupun reaksi (Muninjaya 2012). Untuk mencapai suatu tujuan organisasi maka atasan perlu membuat suasana kerja yang menunjang agar bawahan lebih giat untuk mencapa suatu keberhasilan dalam mengerjakan tugasnya (Choiriyah 2015). Pemimpin dengan gaya tidak menyenangkan mengakibatkan kinerja bawahan menurun serta stres yang bisa mempengaruhi menurunnya daya produktivitas kerja pada organisasi (Choiriyah 2015). Pemimpin dengan gaya situasional bisa berdampak pada bawahan menjadi termotivasi dalam melaksanakan tugasnya dan bisa 
menambah keahlian bawahan saat bekerja (Fajriyah \& RJ 2015). Gaya kepemimpinan yang sesuai dengan situasi dan kondisi atau situasional akan berdampak pada bawahan menjadi lebih semangat dalam menjalankan tugas serta kewajibannya dan akan meningkatkan kemampuan bawahan dalam bekerja (Fajriyah \& RJ 2015).

Peneliti melakukan studi pendahuluan di RSD Idaman Kota Banjarbaru hasilnya masih ada ruangan rawat inap yang belum memenuhi standar kepuasan kerja perawat di rumah sakit tersebut yaitu sebesar $\geq 70 \%$. Studi pendahuluan yang dilakukan peneliti pada tanggal 15-16 Oktober 2018 di ruang rawat inap RSD Idaman Kota Banjarbaru dengan metode wawancara dengan 6 perawat pada shift pagi dan siang diruang nuri, cendrawasih, murai, camar, dan kasuari didapatkan hasil 3 dari 6 perawat mengatakan cara kepala ruangan dalam mengambil keputusan tergantung situasi pada saat itu atau situasional dan 3 perawat lainnya mengatakan kepala ruangan dalam mengambil keputusan selalu dirapatkan dan dimusyawarahkan atau bergaya demokratis. Serta semua perawat yang diwawancara mengatakan cara pengambilan keputusan kepala ruangan itu berpengaruh terhadap tingkat kepuasan mereka dalam bekerja.

Karena itu, penting dilakukan penelitian untuk mengetahui hubungan gaya kepemimpinan kepala ruang dengan kepuasan kerja perawat di ruang rawat inap RSD Idaman Kota Banjarbaru.

\section{METODE}

Non-eksperimen merupakan metode penelitian yang dipilih peneliti dengan teknik non-probability sampling berupa sampling kuota. Metode yang digunakan peneliti dengan pendekatan cross sectional. Populasi yaitu seluruh perawat pelaksana pada ruang rawat inap dengan jumlah 119 perawat Sampel yang terlibat dalam penelitian ini yang ada di ruang rawat inap RSD Idaman Kota Banjarbaru sejumlah 102 orang. Kriteria inkulusinya sendiri yaitu bersedia bersedia menjadi responden penelitian. Diambil menggunakan lembar kuesioner gaya kepemimpinan kepala ruang menurut Hersey dan Blanchart yang berjumlah 20 pernyataan dan dibagi menjadi 4 gaya kepemimpinan (telling, selling, participating dan delegating) yang masingmasing diwakilkan 5 pernyataan setiap gaya kepemimpinan. Serta kuesioner kepuasan kerja perawat yang mempunyai 20 pernyataan dan kuesioner sudah baku dari Kemenkes RI 2013 sehingga tidak perlu lagi untuk diuji validitas. Analisis univariat menggunakan deskriptif statistic dengan data yang berskala numerik. Analisis statisti menggunakan uji spearman rho karena pada variable gaya kepemipinan kepala ruang hasil uji normlaitas datanya tidak berdistribusi normal. Hipotesis nya ada hubungan gaya kepemimpinan kepala ruang dengan kepuasan kerja perawat diruang rawat inap RSD Idaman Kota Banjarbaru. 
HASIL

Tabel 1 Karakteristik Perawat Pelaksana di Ruang Rawat Inap RSD Idaman Kota Banjarbaru menurut umur, jenis kelamin, pendidikan, lama kerja dan jenjang karir $(\mathbf{n}=\mathbf{1 0 2})$

\begin{tabular}{llll}
\hline Karakteristik & & $\mathrm{n}$ & $\%$ \\
\hline Umur & 1. $17-25$ tahun & 26 & 25.5 \\
& 2. $26-35$ tahun & 63 & 61.8 \\
& 3. $36-45$ tahun & 12 & 11.8 \\
Jenis & 4. $46-55$ tahun & 1 & 1 \\
Kelamin & 1. Perempuan & 62 & 60,8 \\
\multirow{5}{*}{ Pendidikan } & 2. Laki-Laki & 40 & 39,2 \\
& 1. DIII & 67 & 65,7 \\
& 2. DIII+S.Kep & 6 & 5,9 \\
Lama Kerja & 1. $\leq 3$ tahun & 61 & 59.8 \\
& 2. $>3$ tahun & 41 & 40.2 \\
Jenjang Karir & 1. PK I & 76 & 74,5 \\
& 2. PK II & 18 & 17,6 \\
& 3. PK III & 8 & 7,8 \\
\hline
\end{tabular}

Tabel 1 Karakteristik umur terbanyak adalah 26-35 tahun sebanyak $61,8 \%$. Jenis kelamin menunjukan data paling banyak jenis kelamin perempuan sebanyak $60,8 \%$. Pendidikan terbanyak responden adalah DIII dengan 65,7\%. Lama kerja terbanyak adalah $\leq 3$ tahun sebanyak 59,8\%. Jenjang karir terbanyak responden adalah PK I sebanyak $74,5 \%$.

Tabel 2 Interpretasi kepuasan kerja perawat di RSD Idaman Kota Banjarbaru berdasarkan persepsi perawat $(n=102)$

\begin{tabular}{lll}
\hline Mean & Min-Max & SD \\
\hline 62,82 & $38-96$ & 11,311 \\
\hline
\end{tabular}

Tabel 2 menunjukan rata-rata nilai kepuasan kerja perawat di RSD Idaman Kota Banjarbaru sebanyak 62,82 dengan nilai minimal 38, nilai maksimal 96 dan standar deviasi 11,311.

Tabel 3 Interpretasi gaya kepemimpinan kepala ruang di RSD Idaman Kota Banjarbaru berdasarkan persepsi perawat $(\mathbf{n}=102)$

\begin{tabular}{lll}
\hline Mean & Min-Max & SD \\
\hline 57,90 & $33-64$ & 6,736 \\
\hline
\end{tabular}

Tabel 3 memperlihatkan rata-rata gaya kepemimpinan kepala ruang di RSD Idaman Kota Banjarbaru sebanyak 57,90 nilai minimal, nilai maksimal 64 dan standar deviasi 6,736. Berdasarkan hasil ini membuktikan bahwa kepala ruangan di RSD Idaman Kota Banjarbaru sering menggunakan gaya kepemimpinan ini. Pada penelitian ini apabila semakin tinggi skor gaya kepemimpinan kepaIa ruang rawat inap yang di persepsikan perawat semakin sering juga gaya kepemimpinan ini digunakan oleh kepala ruangan.

Tabel 4 Gaya kepemimpinan situasional kepala ruang di RSD Idaman Kota

Banjarbaru berdasarkan persepsi perawat $(n=102)$

\begin{tabular}{lc}
\hline \multicolumn{1}{c}{$\begin{array}{c}\text { Gaya Kepemimpinan } \\
\text { Situasional }\end{array}$} & $\begin{array}{c}\text { Hasil Dalam } \\
\%\end{array}$ \\
\hline Telling & 16,7 \\
Selling & 4,9 \\
Participating & 33,3 \\
Delegating & 3,9 \\
Lebih dari satu gaya & 41,2 \\
kepemimpinan situasional & \\
\hline \multicolumn{2}{c}{ Total } \\
\hline
\end{tabular}

Tabel 4 menunjukkan hasil gaya kepemimpinan situasional kepala ruang rawat inap RSD Idaman Kota Banjarbaru. Berdasarkan tabel bisa dilihat dari ke empat 
gaya yang terbanyak adalah gaya kepemimpinan situasional dengan participating sebesar 33,3\% disusul telling $14,7 \%$, selling $4,9 \%$ dan delegating 3,9\%. Serta sebesar $41,2 \%$ perawat mempersepsikan lebih dari satu gaya kepemimpinan situasional.

Tabel 5 Hubungan gaya kepemimpinan kepala ruang dengan kepuasan kerja perawat di RSD Idaman Kota Banjarbaru $(\mathbf{n}=\mathbf{1 0 2})$

\begin{tabular}{lcc}
\hline \multicolumn{1}{c}{ Variabel } & p-value & $\begin{array}{l}\text { Koefisien } \\
\text { Korelasi (r) }\end{array}$ \\
\hline $\begin{array}{l}\text { Gaya } \\
\text { Kepemimpinan } \\
\text { Kepala Ruang }\end{array}$ & 0,000 & 0,417 \\
\hline $\begin{array}{l}\text { Kepuasan Kerja } \\
\text { Perawat }\end{array}$ & & \\
\hline
\end{tabular}

Tabel 5 ini menunjukan hubungan gaya kepemimpinan kepala ruang dengan kepuasan kerja perawat di ruang rawat inap RSD Idaman Kota Banjarbaru dari 102 responden yang didapatkan nilai signifikan gaya kepemimpinan kepala ruang dengan kepuasan kerja perawat di ruang rawat inap sebesar $(\mathrm{p}=0,000)$. Analisis hasil didapat $\mathrm{p}$ value $<\alpha \quad(0,000<0,05)$ serta koefisien korelasi (r) sebesar 0,417 maka $\mathrm{H}_{\mathrm{o}}$ ditolak yang berarti ada hubungan/korelasi signifikan antara gaya kepemimpinan kepela ruang dengan kepuasan kerja perawat di ruang rawat inap RSD Idaman Kota Banjarbaru terhadap kekuatan hubungan cukup kuat dan arah hubungan positif yang berarti semakin sering kepala ruangan menggunakan gaya kepemimpinan situasional maka semakin tinggi tingkat kepuasan kerja perawat di ruang rawat inap.

\section{PEMBAHASAN}

Pembahasan meliputi bahasan hasil penelitian secara terpadu. Membahas hipotesis yang dipadukan dengan hasil penelitian. Pembahasan juga meliputi penjelasan teoritis baik secara kualitatif maupun kuantitatif.

Pada penelitian ini jenjang karir dapat meningkatkan prestasi perawat dalam melakukan pencapaian, agar tidak terjadi perpindahan perawat ke tempat lain, kepatuhan perawat meningkat dan bakat. Pada penelitian ini kepuasan kerja perawat dibeberapa ruangan yang diteliti belum mencapai standar kepuasan kerja rumah sakit sebesar $\geq 70 \%$. Serta juga belum mencapai standar kepuasan kerja menurut SPM (Standar Pelayanan Minimal) 2008 sebesar $\geq 90 \%$. Penelitian ini sejalan dengan penelitian Rizany, Hariyati, Afifah, dan Rusdiyansyah (2019) didapatkan kepuasan perawat pada penelitian ini rendah dikarenakan kurangnya gaji dan pengembangan karier (Rizany et al 2019). Penelitian Maryanto dkk (2013) tidak puas dalam bekerja disebabkan keadaan tempat kerja kurang mendukung, teman bekerja kurang mendukung serta pengawasan kurang baik (Maryanto, Tri \& Singgih 2013).

Pada penelitian ini apabila semakin tinggi skor gaya kepemimpinan kepaIa ruang rawat inap yang di persepsikan perawat semakin sering juga gaya kepemimpinan ini digunakan oleh kepala ruangan. Penelitian Putra (2017) penerapan gaya kepemimpinan situasional yang bagus bisa menimbulkan bawahan yang puas terhadap pekerjaannya sehingga tujuan dari perusahaan bisa tercapai (Putra 2017). Penelitian ini juga sesuai dengan pendapat Agustina, Kusmintardjo, dan Huda (2017) 
yang mana dalam satu kelompok memerlukan gaya kepemimpinan yang tidak sama. Perbedaan gaya kepemimpinan yang diterapkan terhadap kelompok satu dengan yang lain dikarenakan kemampuan setiap individu yang berbeda-beda pula dan disinilah keuntungan seorang pemimpin menggunakan gaya kepemimpinan situasional karena pemimpin mampu memilih gaya kepemimpinan yang dipakai pada situasi yang tepat pada bawahannya (Agustina, Kusmintarjo \& Muhammad 2017).

Penelitan ini dari ke empat gaya yang terbanyak adalah gaya kepemimpinan situasional dengan participating sebesar $33,3 \%$ disusul telling $14,7 \%$, selling $4,9 \%$ dan delegating 3,9\%. Serta sebesar 41,2\% perawat mempersepsikan lebih dari satu gaya kepemimpinan situasional. Penelitian Hidayati, Utami dan Prasetya (2015) menyatakan gaya kepemimpinan situasional dengan participating lebih signifikan dibanding ketiga gaya yang lain. Hal ini berarti pemimpin memberikan dukungan kepada bawahan sehingga terjadi komunikasi dua arah (Hidayati, Hamidah \& Utami 2015). Motivasi pekerja akan tumbuh jika pemimpin melibatkan bawahannya sehingga kemampuan mereka berkembang. Kepercayaan diri perawat juga akan tumbuh seiring adanya dukungan dari pemimpin sehimgga mereka mampu menjalankan tugasnya secara maksimal (Hidayati, Hamidah \& Utami 2015). Penelitian Widawati dan Sari (2013) berpendapat responden memaknai pemimpin yang menggunakan gaya kepemimpinan situasional dengan telling akan memberikan beban tugas yang tinggi. Akan tetapi pemimpin menyampaikan terlebih dahulu ketentuan tahapan pekerjaan yang akan dilakukan secara jelas
(Widawati \& Wirachmaria 2013). Kelemahan pada gaya situasional dengan telling tidak cocok digunakan pada bawahan yang tingkat kematangan tinggi. Pemimipin pada gaya situasonal ini tidak memberi suatu pengakuan terkait kemampuan bawahannya. Seperti yang diketahui bawahan dengan kematangan yang tinggi memerlukan pengakuan dari pemimpin, yang mana selalu ingin dilibatkan dalam pengambilan keputusan terkait kerja yang dilakukan secara mandiri (Syah 2017). Selling atau menjual memiliki ciri hubungan interpersonal antara pimpinan dengan staf lebih dekat dan intensif, menjelaskan tentang keputusan yang akan diambil serta diberikan kesempatan untuk bertanya. Pemimpin masih mengontrol untuk kesiapan staf jika kerjanya masih belum memadai mengarahkan dan mendukung kebutuhan stafnya akibatnya tugas diharapkan dapat selesai dengan baik (Usman 2011; Syah 2017). Delegating atau pendelegasian yang mana situasi seperti ini, pemimpin menyerahkan tanggung jawab penuh terhadap staf sebab sudah dianggap sangat siap melaksankan tugasnya dan bisa mengambil keputusan yang bertanggung jawab. Dalam situasi seperti ini, pemimpin mulai mengurangi hubungan interpersonalnya dengan staf dan juga mengurangi pengaruhnya terhadap tugastugas kelompok (Winarni 2011). HaI ini sejaIan dengan penelitian Widawati dan Sari (2013) yang mengatakan bahwa gaya kepemimpinan situasional dengan delegating ini cocok terhadap kematangan bawahan yang tinggi (Widawati \& Wirachmaria 2013). Pendapat oleh Agustina, Kusmintardjo, dan Huda (2017) yang mengatakan pemimpin tidak hanya menggunakan satu gaya dalam memimpin tetapi dalam satu kelompok memerlukan 
gaya yang berbeda-beda (Agustina, Kusmintarjo \& Muhammad 2017). Perbedaan gaya yang diterapkan pada kelompok satu dengan yang lain dikarenakan kemampuan yang berbedabeda pada setiap orang dan inilah keuntungan suatu pemimpin menggunakan gaya kepemimpinan situasional dikarenakan pemimpin mampu memilih gaya yang diterapkan pada situasi dan kondisi yang tepat untuk bawahannya (Fajriyah \& RJ 2015).

Pada penelitian ini ada hubungan/korelasi signifikan antara gaya kepemimpinan kepala ruang dengan kepuasan kerja perawat di ruang rawat inap RSD Idaman Kota Banjarbaru terhadap kekuatan hubungan cukup kuat dan arah hubungan positif yang berarti semakin sering kepala ruangan menggunakan gaya kepemimpinan situasional maka semakin tinggi tingkat kepuasan kerja perawat di ruang rawat inap. Penelitian yang dilakukan oleh Suryokoco dkk (2017) mendapatkan gaya kepemimpinan situasional berpengaruh signifikan dengan kepuasan kerja perawat. Gaya kepemimpinan yang sesuai situasi dan kondisi atau gaya kepemimpinan situasional dapat meningkatkan kinerja keryawan dalam melaksanakan tugasnya. Menerapkan gaya kepemimpinana situasional yang baik akan menghasilkan bawahan yang puas terhadap pekerjaannya (Suryokoco, Nova \& Bramastyo 2017). Hasil penelitian Hidayati (2015) mendapatkan hasil penerapan gaya kepemimpinan situasionaI yang signifikan akan meningkatkan kepuasan kerja pada bawahan (Hidayati, Hamidah \& Utami 2015). Berdasarkan penelitian Hidayat, Djamhur dan Ika (2013) membuktikan bahwa gaya kepemimpinan situasional berpengaruh signifikan terhadap kepuasan kerja yang mana berpengaruh sebesar 48,0\% dan sisanya 51,2\% dipengaruhi oleh variabel lain. Pemimpin adalah seorang yang memberikan perintah atau petunjuk dalam peIaksanaan kerja. Berbagai cara pemimpin bisa menyenangkan bagi karyawannya atau bisa juga tidak, hal ini dapat mempengaruhi kepuasaan seseorang (Hidayat, Djamhur \& Ika 2013). Hasil r = 0,417 maka menunjukan bahwa terdapat kekuatan hubungan cukup. Peneltian ini juga dapat dilihat bahwa bukan hanya gaya kepemimpinan mempengaruhi dengan tingkat kepuasan kerja tetapi terdapat faktor lain yang berpengaruh seperti gaji, kondisi tempat kerja, dll. Penelitian ini didukung oleh Maryanto dkk (2013) dimana kondisi kerja yang tidak mendukung maka perawat akan merasakan ketidakpuasan kerja, teman bekerja tidak mendukung serta mutu pengawasan yang tidak baik (Maryanto, Tri \& Singgih 2013). Penelitian oleh Putra, Wahyuni, dan Kurniawan (2018) yang menyatakan rekan kerja berpengaruh terhadap kepuasan yang dirasakan pekerja (Putra, Ida \& Bina 2018).

\section{KESIMPULAN}

Kesimpulan pada penelitian adalah ada hubungan yang signifikan antara gaya kepemimpinan kepala ruang dengan kepuasan kerja perawat di ruang rawat inap RSD Idaman Kota Banjarbaru denga nilai p-value 0,000 dengan kekuatan hubungan 0,417 (cukup). Peneliti selanjutnya disarankan melanjutkan penelitian ini dengan mengganti variabel kepuasan kerja dengan tingkat kematangan bawahan menggunakan gaya kepemimpinan yang sama. Karena teori gaya kepemimpinan situasional ini juga salah satunya didasarkan saling pengaruh antara tingkat kematangan bawahan. Peneliti selanjutnya 
juga disarankan mencari karakteristik kepala ruangan seperti umur, pendidikan dll untuk mengetahui apakah ada pengaruh karakteristik kepala ruangan terhadap gaya kepemimpinan yang dipakai.

\section{DAFTAR PUSTAKA}

Agustina, M., Kusmintardjo \& Muhammad H. 2017 . Kepemimpinan Situasional di Sekolah. Universitas Negeri Malang

Choiriyah, U. 2015. Gaya Kepemimpinan Dan Kinerja Pegawai (Dinas Sosial Kabupaten Malang). Prodi Ilmu Administrasi Negara-FISIPUniversitas Muhammadiyah Sidoarjo Jalan Mojopahit 666 B, Sidoarjo; Vol. 3, No. 1, 1-116.

Fajriyah, S., \& RJ I. P. 2015. Pengaruh Gaya Kepemimpinan Dan Lingkungan Kerja Terhadap Kepuasan Kerja Karyawan (Studi Kasus Pada PT. Bank Central Asia, Tbk. Cabang Utama Cikarang, Jawa Barat). Fakultas Ekonomi dan Bisnis Universitas Mercu Buana; Vol. 1 No. 3.

Hidaya, N., Indahwaty S. \& Alimin M. 2015. Gambaran Faktor Kepuasan Kerja Karyawan di Rumah Sakit Universitas Hasanuddin. Fakultas Kesehatan Masyarakat Universitas Hasanuddin, Makassar.

Hidayat, N., Djamhur H. \& Ika R. 2013. Pengaruh Gaya Kepemimpinan Situasional dan Budaya Organisasi Terhadap Kepuasan Kerja (Studi Kasus Pada Karyawan PT. Taspen (Persero) KUC Malang). 2013

Hidayati, S., Hamidah N. \& Utami A. P. 2015. Pengaruh Gaya Kepemimpinan Situasional Terhadap Kepuasan Kerja dan Kinerja Karyawan (Studi Pada Karyawan Divisi Tower \& Approach Terminal (Twr\&App-Tma) Airnav Indonesia Kantor Cabang Aero Traffic Control Soekarno Hatta ). Fakultas Ilmu Administrasi Universitas Brawijaya, Malang. Jurnal
Administrasi Bisnis (JAB); Vol. 26 No. 1

Karimah, I. 2013. Perbandingan Tingkat Kepuasan Kerja Perawat Rumah Sakit Pemerintah dan Rumah Sakit Swasta di Kota Makassar. Jurusan Kesehatan Masyarakat, Fakultas Kedokteran dan Ilmu Kesehatan, Universitas Islam Negeri Alauddin Makassar.

Mangi, J. L. 2015. Analisis Hubungan Gaya Kepemimpinan, Karakteristik Bawahan, dan Komitmen Organisasi dengan Kepuasan Kerja Perawat di RS Stella Maris Makassar. Fakultas Kedokteran Universitas Hasanuddin, Makassar.

Maryanto., Tri I. P., \& Singgih S. 2013. Hubungan Gaya Kepemimpinan Kepala Ruang dengan Kepuasan Kerja Perawat di Rumah Sakit Swasta di Demak. Jurnal Managemen Keperawatan; Vol. 1, No. 2.

Muninjaya, Dr. A. A. Gde. 2012. Manajemen Kesehatan. Edisi 3.

Putra, I. P. 2017. Pengaruh Gaya Kepemimpinan Situasional Dan Motivasi Kerja Terhadap Kepuasan Kerja Karyawan (Studi Pada Alpha Hotel Pekanbaru). University of Riau, Bina Widya Campus. JOM FISIP; Vol. 4 No. 2.

Putra, K. D. Y., Ida W. \& Bina K. 2018. Hubungan Supervisi, Rekan Kerja, Gaji, Keamanan Kerja, Kondisi Kerja, Promosi Jabatan dan Jenis Pekerjaan dengan Kepuasan Kerja (Studi Kasus Pada Karyawan Koperasi Simpan Pinjam X di Kabupaten Pemalang, Jawa Tengah). Jurnal Kesehatan Masyarakat (E-Journal); Vol. 6, No. 4

Rizany I., Rr. Tutik S. H., Efy A. dan Rusdiyansyah. 2019. The Impact of Nurse Scheduling Management on Nurses' Job Satisfaction in Army Hospital: A Cross-Sectional Research. SAGE Open; April-June: 1-9. 
Sunyoto, D. 2012. Manajemen Sumber Daya Manusia. Jakarta: PT Buku Seru.

Suryokoco, J., Nova R. \& Bramastyo K. N. 2017. Pengaruh Gaya Kepemimpinan Situasional, Reward, Punishment dan Performance Contract Terhadap Kepuasan Kerja Pt. Multi Indowood Gresik. Prodi Manajemen Fakultas Ekonomi Dan Bisnis, Universitas Bhayangkara Surabaya. Jurnal Manajemen Branchmark; Vol 3 Issue 3

Susanti, F. A., \& Mulyaningsih. 2015. Sistem Penghargaan Meningkatkan Kepuasan Kerja Perawat. Jurnal Prosiding Nasional APIKES-AKBID Citra Medika Surakarta; ISBN: 978-60273685-4-9.

Syah, M. A. 2017.. Pengaruh Gaya Kepemimpinan Situasional dan Komunikasi Organisasi Terhadap Kinerja Karyawan (Studi Eksplanatif Kuantitatif Pada CV. Putra Nugraha Sentosa Mojosongo). Program Studi Ilmu Komunikasi, Fakultas Komunikasi dan Informatika, Universitas Muhammadiyah Surakarta.

Usman, Prof. Dr. H. 2011. Manajemen Teori, Praktik, dan Riset Pendidikan. Jakarta: Cetakan ke-3. PT Bumi Aksara.

Widawati, L. \& Wirachmaria S. 2013. Studi Deskriptif Tentang Gaya Kepemimpinan Manager Operasional PT. Bank "X" Cabang Pamanukan. Psympathic, Jurnal Ilmiah Psikologi; Vol 6, No 2

Winarni, F. 2011. Modul Kepemimpinan. Program Hibah Kompetensi Berbasis Instusi (PHKI). Universitas Negeri Yogyakarta 